\title{
Evaluasi Program Sistem Pertanian Terintegrasi (Simantri)
}

\author{
Ni Putu Andepi Dewi ${ }^{* 1}$, I Nyoman Sujana², Made Ary Meitriana ${ }^{3}$ \\ Program Studi Pendidikan Ekonomi \\ Universitas Pendidikan Ganesha \\ Singaraja, Indonesia
}
e-mail: putuandepidewi@gmail.com*1, sujanatbn@yahoo.com², ary.meitriana@undiksha.ac.id ${ }^{3}$

\begin{abstract}
Abstrak
Riwayat Artikel Tanggal diajukan: 16 Januari 2020

Tanggal diterima : 4 Juni 2020

Tanggal dipublikasikan: 29 Juni 2020

Tujuan dilakukannya penelitian ini adalah mengetahui tingkat efektivitas dari program Simantri di Desa Mengani tahun 2018 ditinjau dari segi context, input, process, dan product. Instrument pengumpulan data berupa kuesioner dan dokumentasi. Subjek dalam penelitian ini yaitu anggota Simantri di Desa Mengani dengan jumlah 39 orang dan objek dari penelitian ini adalah program Simantri. Data dianalisis dengan deskriptif menggunakan skor standar (z-skor) yang ditransformasikan dalam T-skor kemudian diferivikasi ke dalam prototype dari Glickman. Dari analisis data diperoleh hasil dari masing-masing dimensi yaitu context memperoleh hasil positif $(+)$, input memperoleh hasil negatif $(-)$, process memperoleh hasil positif $(+)$ and product juga memperoleh hasil yang positif (+), maka posisi CIPP $(+-++)$ di kuadran II. Sehingga dapat disimpulkan bahwa pelaksanaan program Simantri di Desa Mengani termasuk dalam kategori cukup efektif.
\end{abstract}

Pengutipan:

Dewi, N. P. A.,

Sujana, I. N. \&

Meitriana, M. A.

(2020). Evaluasi

Program Sistem

Pertanian

Terintegrasi

(Simantri). Jurnal

Pendidikan

Ekonomi

Undiksha, 12 (1)

107-116
Kata kunci: evaluasi program; program simantri; model CIPP

\begin{abstract}
This study aimed at investigating the extent of effectiveness of the Simantri in Mangani Village in 2018 in terms of context, input, process and product. The instruments that were used in this study were questionnaires and documentation. The members of Simantri in Mengani Village consisted oif 39 people were used as the subject of the study and the object was the Simantri program. This study used descriptive analysis by using standard score (z-crore) transformed into T-score then verified into the prototype from Glickman. The result of the data analysis revealed that from each dimension, context obtained a positive result (+), input obtained a negative result (-), the process obtained a positive result (+) and the product also obtained a positive result (+), then the CIPP position (+ +++$)$ in quadrant II. So, it can be concluded that the implementation of the Simantri program in Mengani Village was included in quite effective category.
\end{abstract}

Keywords : program evaluation, simantri program, CIPP model 


\section{PENDAHULUAN}

Evaluasi merupakan kegiatan pengumpulan informasi. Evaluasi dapat dipergunakan sebagai penentuan alternatif yang tepat ketika mengambil sebuah keputusan (Arikunto \& Jabar, 2007). Dale (dalam Sardjo, 2016) menyatakan evaluasi adalah suatu penelitian yang bersifat menyeluruh, dilaksanakan pada waktu tertentu terhadap suatu program atau hasilhasil yang dicapai oleh suatu organisasi. Evaluasi menjadi bagian yang melekat dan berkelanjutan dalam proses program pemerintah (Pratiwi, Pascarani, \& Winaya, 2016). Semua aktivitas yang dilakukan membutuhkan penilaian atau evaluasi (Sawerah, 2012). Evaluasi program merupakan cara untuk mengetahui sejauhmana tingkat efektivitas program dari komponen-komponenya dalam mendukung pencapaian tujuan program (Arikunto \& Jabar, 2014). Menurut Tayibnapis (2000) evaluasi program merupakan usaha yang dilakukan guna mengetahui tingkat efektivitas sebuah program. Sedangkan menurut Nonci (2017) evaluasi program adalah gerakan yang dilakukan guna mengetahui sejauhmana tingkat efektivitas program. Jadi evaluasi program merupakan aktivitas pengumpulan informasi yang digunakan untuk melihat sejauhmana tingkat efektivitas dari sebuah program dan sebagai bahan acuan dalam pengambilan keputusan. Evaluasi dilaksanakan dengan maksud untuk mengetahui kesesuaian efektivitas kegiatan antara perencanaan dan pelaksanaan serta keberhasilan program (Pantouw, Ngangi, \& Lolowang, 2017). Manfaat evaluasi adalah untuk menyajikan informasi sebagai masukan untuk pembuat keputusan (Yuriani, 2012). Selain itu dengan melakukan evaluasi dapat membantu para pengambil keputusan untuk menentukan tindak lanjut dari sebuah program yang telah dilaksanakan. Dengan kata lain evaluasi memegang peran yang sangat penting karena hasil evaluasi menentukan sejauhmana tujuan program tersebut telah tercapai dan dapat membantu dalam pengambilan keputusan terhadap program tersebut (Tayibnapis, 2000).

$$
\text { Salah satu program yang }
$$

dilaksanakan dalam upaya pengembangan

bidang pertanian di Provinsi Bali,
Pemerintah Bali mencanangkan program Sistem Pertanian Terintegrasi (Simantri). Simantri ini diatur oleh Peraturan Gubernur Bali Nomor 29 Tahun 2010 tentang Keberlanjutan Program Simantri yang selanjutnya disebut Pergub. Bali No. 29 Tahun 2010. Pengertian Simantri dalam pergub. Bali No. 29 Tahun 2010 diartikan sebagai inovasi dalam adopsi teknologi pertanian karena merupakan peningkatan model percontohan guna percepatan teknologi kepada masyarakat perdesaan. Kegiatan pengembangan usaha Simantri dilaksanakan dalam rangka pemberdayaan petani, peternakan, perkebunan dan nelayan melalui kegiatan yang terintegrasi baik dalam sub sektor maupun sub sistem agribisnis (Peraturan Gubernur Bali Nomor 29 Tahun 2010).

Program ini mulai dilaksanakan pada tahun 2009 yang merupakan suatu program pemberdayaan dalam rangka kesejahteraan petani, menyusutkan angka kemiskinan dan menurunkan tingkat pengangguran (Aryana, Budhi, \& Yuliarmi, 2016). Menurut Parining (2011) program ini juga bertujuan untuk mengurangi pencemaran kimia dalam tanah dan untuk mengembangkan kelompok kelompok Simantri untuk menjaga kesejahteraan anggotanya. Program Simantri juga bertujuan untuk meningkatkan kuantitas produksi dengan harapan dapat meningkatkan pendapatan dan kesejahteraan petani (Dewi, Utama, \& Yuliarmi, 2017). Pada dasarnya Simantri merupakan penggabungan aktivits dari vertikal dan horizontal yang dimulai dari proses perencanaan, perumusan kebijakan serta implementasi (Anugrah, Sarwoprasodjo, Suradisastra, \& Purnaningsih, 2014). Usaha yang dilaksanakan pada program Simantri yakni memelihara sapi, membuatan pupuk kompos, pupuk biogas, bio urine, pupuk padat maupun cair dan bio pestisida (Dananjaya, Suparta, \& Setiawan, 2014). Penerapan pertanian terintegrasi seringkali disebut dengan sistem pertanian tanpa limbah. Limbah yang dihasilkan dimanfaatkan kembali sebagai sumber energi dan nutrisi serta dapat memiliki nilai guna yang tinggi.

Konsep Simantri yang diinisiasi oleh Gubernur Bali yang terinspirasi dari model 
pengembangan Prima Tani yang diintroduksikan melalui Balai Pengkajian Teknologi Pertanian (BPTP) Provinsi Bali. Gambaran kegiatan pertanian terintegrasi disampaikan dalam presentasi model Prima Tani di hadapan Gubernur dan pejabat publik lainnya menjadi momentum awal lahirnya konsep adopsi model Prima Tani menjadi Simantri guna untuk mendukung program strategis daerah. Konsep ini merupakan hasil transformasi kegiatan Prima Tani di Provinsi Bali mengembangkan pola integrasi tanaman ternak pada SUID keluarga. Konsep ini kemudian dirancang menjadi program Simantri melalui arahan dan ide pemikiran Gubernur Bali kepada instansi teknis terikat di lingkup Pemprov Bali dan BPTP Bali. Program ini memperoleh bantuan pendanaan, fasilitas, dan komitmen politik pimpinan daerah yang sinergisitas program strategi daerah penganggaran yang berkelanjutan.

Sasaran dari kegiatan Simantri yakni Gabungan Kelompok Tani (Gapoktan) pada satu wilayah perdesaan. Menurut Peraturan Menteri Pertanian Nomor: 67/ Permentaan/ SM. 050/ 12/ 2016 Gapoktan merupakan gabungan beberapa kelompok tani yang bekerjasama untuk meningkatkan perekonomian dan efisiensi usaha. Pembentukan Gapoktan adalah sebagai organisasi/ badan usaha pemasaran yang aktif, kreatif, inovatif dan berbasis emarketting. Target dari penguatan gapoktan ini adalah menjadikan daerah pertanian seperti supermarket hasil pertanian yang menyediaka beragam produk pertanian mulai dari pengemasan, promosi hingga distribusi. Gapoktan memiliki fungsi diantara lain adalah sebagai unit penyedia sarana dan prasarana produksi, unit usahatani, unit pengolahan dan unit usaha pemasaran serta unit usaha keuangan mikro.

Pada tahap awal kegiatan program ini, pendanaan disediakan oleh Pemprov Bali dalam bentuk paket mulai dari pengembangan komonditi tanaman pangan, perikanan, peternakan, pengembangan ternak sapi atau kambing, kandang koloni, bangunan instalasi bio gas, bangunan instalasi bio urine dan bangunan pengolahan kompos dan pakan serta pengembangan tanaman. Kegiatan utama yang dilaksanakan pada program ini yakni kegiatan budidaya (ternak sapi sesuai potensi daerah), pengolahan limbah tanaman, pengolahan limbah ternak, serta pemanfaatannya, menuju kepada kelompok yang mandiri akan pangan dan papan.

Adapun maksud dirancangnya program Simantri ini adalah sebagai perkembangan diversifikasi usaha pertanian secara terpadu dan berwawasan agribisnis, salah satu upaya pengentasan kemiskinan, pengurangan pengangguran, mendukung pembangunan ramah lingkungan, Bali bersih dan hijau (clean and green), program Bali Organik menuju Bali Mandara, kegiatan integrasi tanaman dan ternak dengan kelengkapan unit pengolahan kompos, pakan, instalasi bio urine, dan biogas serta peningkatan pendapatan petani.

Keberhasilan program yang dijalankan di Provinsi Bali khususnya Program Sistem Pertanian Terintegrasi (Simantri) dapat dinilai dengan output yang dihasilkan sesuai dengan apa yang ditargetkan dan mampu menunjukkan efektivitas yang baik.

Menurut Tayibnapis (2000) terdapat beberapa model evaluasi program yang popular dan dapat dipakai sebagai strategi atau pedoman kerja pelaksanaan evaluasi program diantaranya: (1) Model Evaluasi CIPP (Context, Input, Process, and Product) adalah model evaluasi yang berorientasi kepada pemegang keputusan untuk membantu administrator membuat keputusan. (2) Model Evaluasi UCLA, dalam model evaluasi ini terdapat lima tahapan yang dilaksanakan dalam evaluasi yakni perencanaan, pengembangan, dan implementasi, hasil serta dampak. (3) Model Evaluasi Brinkerhoff dimana Brinkerhoff \& Cs (1983) mengemukakan bahwa terdapat tiga golongan evaluasi yang disusun berdasarkan gabungan dari elemen-elemen yang sama yaitu Fixed vs Emergent Evaluation Design, Formative vs Sumative Evaluation, and Experimental and Quasi Experimental Design vs Natural/ Unobtrusive Inquary. (4) Model Evaluasi Stake atau Model Countenance pada model ini, masukan, proses dan hasil data dibandingkan tidak hanya untuk menentukan apakah ada perbedaan tujuan dengan keadaan yang sebenarnya, tetapi, 
juga dibandingkan dengan standar absolut untuk menilai manfaat program.

Kecamatan Kintamani Bangli terdiri dari beberapa desa. Salah satunya adalah Desa Mengani. Desa ini merupakan salah satu desa yang merasakan bantuan program Simantri. Besarnya bantuan yang diterima adalah Rp. 200.000.000. Kelompok Simantri di Desa ini memanfaatkan dan tersebut untuk membeli bibit sapi sampai pembuatan kadang koloninya. Setelah mendapatkan bantuan kelompok tani di Desa ini melaksanakan kegiatan integrasi sebagaimana yang telah tercantum dalam Peraturan Gubernur Bali Nomor 29 Tahun 2010. Namun seiring dengan berjalannya waktu kegiatan integrasi seperti pengolahan kotoran sapi menjadi pupuk dan biogas menjadi tidak efektif karena kurangnya partisifasi dari anggota kelompok selain kurangnya partisipasi dari kelompok alat yang digunakan untuk mengolah limbah ternak dalam keadaan rusak.

\section{METODE}

Penelitian ini merupakan penelitian studi evaluatif, di mana penelitian ini mengevaluasi program dari Pemerintah Provinsi Bali yaitu program Simantri. Pada evaluasi program ini akan dilihat tingkat efektivitas yang ditinjau dari segi context, input, process, dan product. Subjek penelitian ini adalah anggota Simantri yang berjumlah 39 orang serta objek penelitian ini adalah program bantuan Simantri.

Sumber pada penelitian ini terdiri dari data primer dan data sekunder. Data primer berupa skor dari kuesioner tentang evaluasi program Simantri. Data sekunder penelitian ini berupa dokumen nama-nama anggota kelompok Simantri. Jenis data yang digunakan dalam peneltian ini ialah data kuantitatif.

Instrumen pengumpulan data berupa kuesioner dan dokumentasi. Kuesioner dipergunakan untuk mendapatkan informasi yang relevan dengan tujuan penelitian. Sedangkan dokumentasi dipergunakan untuk mengumpulkan data terkait dengan nama-nama dari kelompok Simantri. Opsi jawaban dalam kuesioner yaitu menggunakan skala likert, dengan alternative jawaban Sangat Setuju (SS) diberi skor 5, Setuju (S) diberi skor 4, Kurang Setuju (KS) diberi skor 3, Tidak Setuju (TS) diberi skor 2 dan Sangat Tidak Setuju (STS) diberi skor 1.

Sebelum kuesioner dipergunakan terlebih dahulu harus diuji tingkat validitas dan reliasbilitasnya guna mengetahui sejauh mana ketepatan dan kecermatan suatu instrument yang digunakan. Pengujian validitas dan reliabilitas dibantu dengan menggunakan Statistic Product and Service Solution (SPSS) for Wndows versi 16,0.

Data yang telah diperoleh dari dimensi yang diukur (context, input, process, dan product) dianalisis secara kuantitatif dengan menggunakan analisis deskriptif. Data primer yang diperoleh akan dianalisis terlebih dahulu dengan mengolah skor mentah untuk disajikan dalam bentuk tabel distribusi frekuensi bergolong. Dalam studi evaluasi program data dianalisis menggunakan skor standar atau Z-score yang selanjutnya ditransformasikan ke dalam bentuk T-score. Sebelum data dianalias, semua data dicari rerata (mean) dan Standar Deviasi (SD).

Setelah data diproses kemudian akan dianalisis secara deskriptif dibantu dengan menggunakan softwear aplikasi Microsoft Excel for Windows. Data dalam penelitian ini dianalisis secara kuantitatif dengan menggunakan statistic deskriptif. Untuk menentukan kualitas program, data terlebih dahulu dianalisis menggunakan skor standar atau z-score yang selanjutnya ditarnsformasikan ke dalam T-score kemudian diverifikasi kedalam prototype Glickman. Untuk menentukan tingkat keefektifan pelaksanaan program, dilakukan analisis terhadap masing-masing dimensi context, input, process and product melalui analisis prototype Glickman dengan menentukan kecenderungan arah skor standar (z-score) yang sudah ditransformasikan ke dalam T-skor ( $T$ score) yang bernilai positif atau negatif. Dengan ketentuan bahwa jika $\mathrm{T}$ lebih besar atau sama dengan 50 (mean) artinya bernilai positif $(+)$ dan jika T lebih kecil dari 50 (mean) artinya adalah negatif (-). Untuk mengetahui hasil akhir dari masing-masing dimensi context, input, process and product dihitung dengan menjumlahkan skor positif 
(+) dan skor negatif (-). Jika jumlah positifnya lebih banyak atau sama dengan jumlah negatifnya berarti hasilnya positif (sigma Skor $+\geq$ sigma Skor $-=$ positf $(+$ ). Jika jumlah positifnya lebih kecil dari jumlah negatifnya berarti hasilnya negatif.

\section{HASIL DAN PEMBAHASAN}

Hasil

Evaluasi program Simantri, pada dimensi context diukur dengan lima indikator yaitu kebijakan terkait dengan program, tujuan program, kebutuhan, harapan, dan peluang pengembangan diri. Berikut adalah hasil perhitungan dari masing-masing indikator pada dimensi context, setelah data mentah masingmasing indikator ditransformasikan ke dalam T-skor dapat diikthisarkan dalam tabel 1.

Tabel 1. Rekapitulasi Hasil Perhitungan dimensi Context untuk masing-masing Indikator

\begin{tabular}{|c|c|c|c|c|c|}
\hline & \multirow{2}{*}{\multicolumn{2}{|c|}{ Indikator }} & \multicolumn{2}{|c|}{ Frekuensi } & \multirow{2}{*}{ Keterangan } \\
\hline INO & & & $f+$ & Hasil & \\
\hline 1 & \multicolumn{2}{|l|}{ Kebijakan terkait dengan program } & 22 & 17 & Positif \\
\hline 2 & \multicolumn{2}{|l|}{ Tujuan program } & 22 & 17 & Positif \\
\hline 3 & \multicolumn{2}{|l|}{ Kebutuhan } & 29 & 10 & Positif \\
\hline 4 & \multicolumn{2}{|l|}{ Harapan } & 18 & 21 & Negatif \\
\hline 5 & \multicolumn{2}{|l|}{ Peluang pengembangan diri } & 29 & 10 & Positif \\
\hline \multicolumn{3}{|c|}{ 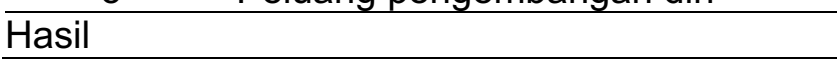 } & \multicolumn{3}{|c|}{+} \\
\hline \multicolumn{2}{|c|}{$\begin{array}{l}\text { Berdasarkan Tabel 1, dari lima } \\
\text { indikator yang dipakai untuk mengukur } \\
\text { dimensi context tampak bahwa empat } \\
\text { indikator sudah dapat membantu } \\
\text { berlangsungnya program Simantri yang } \\
\text { diberikan oleh Pemerintah seperti indikator } \\
\text { kebijakan terkait dengan program, tujuan } \\
\text { program, kebutuhan, dan peluang } \\
\text { pengembangan diri. Untuk indikator } \\
\text { harapan belum mendukung keberhasilan } \\
\text { program Simantri karena nilai } f(+)=18 \\
\text { lebih kecil dari f }(-)=21 \text {. Secara } \\
\text { keseluruhan dimensi context, menunjukkan }\end{array}$} & & \multicolumn{3}{|c|}{$\begin{array}{l}\text { hasil } \sum f(+)=24>\sum f(-)=15 \text {. Sehingg } \\
\text { dapat dinyatakan bahwa dimensi conte } \\
\text { pada evaluasi program Simantri tergolor } \\
\text { efektif. } \\
\text { Evaluasi Program Bantuan Simant } \\
\text { pada dimensi input dapat diukur denge } \\
\text { enam indikator. Berikut adalah ha } \\
\text { perhitungan dari masing-masing indakat } \\
\text { pada dimensi input, setelah data mente } \\
\text { masing-masing indikator ditransformasike } \\
\text { ke dalam T-skor dapat diikthisarkan dala } \\
\text { tabel } 2 \text {. }\end{array}$} \\
\hline \multicolumn{6}{|c|}{ Tabel 2. Rekapitulasi Hasil Perhitungan Dimensi Input Untuk Masing-Masing Indikator } \\
\hline \multirow{2}{*}{ No } & \multirow{2}{*}{ Indikator } & \multicolumn{3}{|c|}{ Frekuensi } & \multirow{2}{*}{ Keterangan } \\
\hline & & $f+$ & f- & Hasil & \\
\hline 1 & Sumber daya manusia & 15 & 24 & - & Negatif \\
\hline 2 & Sosialisasi & 23 & 16 & + & Positif \\
\hline 3 & Manajemen & 16 & 23 & - & Negatif \\
\hline 4 & Sarana prasarana & 11 & 28 & - & Negatif \\
\hline 5 & Petujuk pelaksanaan & 23 & 16 & + & Positif \\
\hline 6 & Dana operasional & 19 & 20 & - & Negatif \\
\hline Hasil & & & & - & \\
\hline
\end{tabular}

Berdasarkan Tabel 2, dari enam indikator yang dipakai untuk mengukur dimensi input tampak bahwa dua indikator sudah dapat mendukung berlangsungnya program Simantri yang diberikan oleh pemerintah seperti indikator sosialisasi dan petunjuk pelaksanaan. Untuk indakator sumber daya manusia, manajemen, sarana prasarana dan dana operasional belum dapat mendukung keberhasilan program Simantri 
karena nilai $f(+)$ lebih kecil dari $f(-)$. Secara keseluruhan dimensi input menunjukkan hasil $\Sigma f(+)=17<\Sigma(-)=22$ atau menghasilkan negatif. Sehingga dapat dinyatakan bahwa secara keseluruhan dimensi input, evaluasi program Simantri di Desa Mengani, Kecamatan Kintamani, Kabupaten Bangli Tahun 2018 tergolong kurang efektif karena dominan kecebnderungan T-skor bernilai negatif.
Evaluasi Program Bantuan Simantri pada dimensi process dapat diukur dengan lima indikator yaitu perencanaan program, seleksi program, penyaluran dana, pemanfaatan dana, dan monitoring. Berikut ini adalah hasil perhitungan dari masingmasing indikator pada dimensi process, setelah data ditansformasikan ke dalam Tskor dapat diikthisarkan dalam tabel 3.

Tabel 3. Rekapitulasi Hasil Perhitungan Dimensi Process untuk Masing-Masing Indikator

\begin{tabular}{llcccc}
\hline \multirow{2}{*}{ No } & \multirow{2}{*}{ Indikator } & \multicolumn{2}{c}{ Frekuensi } & \multirow{2}{*}{ Keterangan } \\
& & $\mathrm{f}+$ & $\mathrm{f}-$ & Hasil & \\
\hline 1 & Perencanaan program & 26 & 13 & + & Positif \\
2 & Seleksi program & 23 & 16 & + & Positif \\
3 & Penyaluran dana & 28 & 11 & + & Positif \\
4 & Pemanfaatan dana & 29 & 10 & - & Negatif \\
5 & Monitoring & 16 & 23 & - & Negatif \\
\hline Hasil & & & & + & \\
\hline
\end{tabular}

Berdasarkan tabel 3, dari lima indikator yang dipakai untuk mengukur dimensi process tampak bahwa tiga indikator sudah dapat mendukung berlangsungnya program Simantri yang diberikan oleh pemerintah seperti perencanaan program, seleksi program dan penyaluran dana. Untuk indikator pemanfaatan dana dan monitoring belum dapat mendukung keberhasilan program Simantri karena nilai $f(+)<f(-)$. Secara keseluruhan dimensi process menunjukkan hasil $\sum f(+)=22>f(-)=17$. Dengan demikian, program bantuan Simantri di Desa Mengani, Kecamatan
Kintamani, Kabupaten Bangli Tahun 2018 tergolong ke dalam kategori efektif.

Evaluasi program bantuan Simantri, pada dimensi product dapat diukur dengan tiga indikator yakni meningkatkan kemampuan kelompok tani dalam mengakses sumber pendanaan, meningkatkan peran simantri dalam memperluas kesempatan kerja dan meningkatkan peran simantri dalam mengentaskan kemiskinan. Berikut adalah hasil perhitungan dari masing-masing indikator product yang telah ditransformasikan ke dalam T-skor dapat diikthisarkan dalam tabel 4 .

Tabel 4. Rekapitulasi Hasil Perhitungan Dimensi Product untuk Masing-Masing Indikator Indikator

\begin{tabular}{llcccc}
\hline \multirow{2}{*}{ No } & \multirow{2}{*}{ Indikator } & \multicolumn{2}{c}{ Frekuensi } & \multirow{2}{*}{ Keterangan } \\
& & $\mathrm{f}+$ & $\mathrm{f}-$ & Hasil & \\
\hline 1 & Sumber Pendanaan & 22 & 17 & + & Positif \\
2 & Kesempatan kerja & 29 & 10 & + & Positif \\
3 & Pengentasan kemiskinan & 21 & 18 & + & Positif \\
\hline Hasil & & & & + & \\
\hline
\end{tabular}

Secara keseluruhan dimensi product menunjukkan hasil $\sum f(+)=32$ lebih besar dari $\sum f(-)=7$. Dengan demikian, dapat dinyatakan bahwa dimensi product, evaluasi program Simantri di Desa Mengani,
Kecamatan Kintamani Kabupaten Bangli tergolong dalam kategori efektif. Bila dianalisis secara keseluruhan terhadap dimensi context, input, process, and product, dimana data telah 
ditansformasikan ke dalam T-skor, maka hasil analisis data dapat dilihat pada tabel 5. Tabel 5. Rekapitulasi Hasil Perhitungan Dimensi Context, Input, Process, and Product Secara Keseluruhan

\begin{tabular}{llllll}
\hline \multirow{2}{*}{ No } & \multirow{2}{*}{ Dimensi } & \multicolumn{2}{l}{ Frekuensi } & \multirow{2}{*}{ Keterangan } \\
& & F + & F - & Hasil & \\
\hline 1 & Konteks & 24 & 15 & + & Positif \\
2 & Input & 18 & 21 & - & Negatif \\
3 & Proses & 22 & 17 & + & Positif \\
4 & Produk & 32 & 7 & + & Positif \\
\hline
\end{tabular}

Berdasarkan tabel 5 tampak bahwa dimensi konteks menunjukkan hasil $\sum f(+)>\sum f(-)$ atau positif, ini disebabkan karena sebagian besar dari indikator pada dimensi konteks sudah dapat mendukung berlangsungnya program Simantri. Pada dimensi input menunjukkan hasil $\Sigma f(+)<\sum f(-)$ atau negatif, ini disebabkan karena sebagian besar dari indikator pada dimensi input belum dapat mendukung efektifnya program Simantri. Dimensi proses menunjukkan hasil $\sum f(+)>\sum f(-)$ atau positif, ini disebabkan karena sebagian besar indikator dari dimensi proses sudah dapat mendukung berlangsungnya program
Simantri. sedangkan pada dimensi produk menunjukkan hasil $\Sigma f(+)>\sum f(-)$ atau positif, ini disebabkan karena sebagian besar indikator pada dimensi produk sudah dapat mendukung berlangsungnya program Simantri.

Jadi secara keseluruhan, pelaksanaan program Simantri di Desa Mengani, Kecamatan Kintamani, Kabupaten Bangli menghasilkan $(+-++)$. Guna mengetahui tingkat keefektifan program Simantri di Desa Mengani, data yang sudah diperoleh pada tabel 5 dianalisis dengan memverifikasikan ke dalam kuadran berikut.

\begin{tabular}{|c|c|c|c|c|c|c|c|}
\hline $\begin{array}{l}\text { I } \\
\text { C } \\
+\end{array}$ & $\begin{array}{l}1 \\
+\end{array}$ & $\begin{array}{l}P \\
+\end{array}$ & $\begin{array}{l}P \\
+\end{array}$ & $\begin{array}{l}\text { II } \\
\text { C } \\
+ \\
+ \\
+ \\
- \\
\text { (C) }\end{array}$ & $\begin{array}{l}\text { I } \\
+ \\
+ \\
- \\
+ \\
\text { Efe }\end{array}$ & $\begin{array}{l}P \\
+ \\
- \\
+ \\
+\end{array}$ & $\begin{array}{l}P \\
- \\
+ \\
+ \\
+\end{array}$ \\
\hline III & & & & IV & & & \\
\hline $\begin{array}{l}\text { C } \\
+\end{array}$ & $\begin{array}{l}1 \\
+\end{array}$ & $\begin{array}{l}P \\
-\end{array}$ & $\begin{array}{l}P \\
-\end{array}$ & $\begin{array}{l}C \\
+\end{array}$ & 1 & $\begin{array}{l}P \\
-\end{array}$ & P \\
\hline - & + & - & + & - & + & - & - \\
\hline+ & - & + & + & - & - & + & - \\
\hline & g & + & + & & $\overline{-}$ & - & + \\
\hline
\end{tabular}

Gambar 1. Prototype Evaluasi Program Simantri diadaptasi dari teori Glickman.

Dari hasil perhitungan seperti Gambar 1 menujukkan nilai CIPP $(+-++)$. Setelah dikonversikan ke dalam kuadran prototype Glickman, maka evaluasi program Simantri di Desa Mengani Kecamatan Kintamani Kabupaten Bangli berada pada kategori kuadran II yaitu cukup efektif. artinya pada tiga dimensi (Context, Process, and Product) tergolong efektif dan dimensi Input tergolong kurang efektif. dengan demikian, program Simantri di Desa Mengani, Kecamatan Kintamani, Kabupaten Bangli Tahun 2018 tergolong cukup efektif.

\section{Pembahasan}

Berdasarkan hasil penelitian ini menunjukkan bahwa evaluasi program bantuan Simantri di Desa Mengani tahun 
2018 tergolong pada kriteria cukup efektif. Pada dimensi konteks, hasil penelitian menunjukkan bahwa secara umum dimensi konteks tergolong dalam kriteria efektif seperti indikator kebijakan terkait dengan program, tujuan program, kebutuhan dan peluang pengembangan diri sudah dapat mendukung berlangsungnya program Simantri yang diberikan oleh pemerintah kepada kelompok tani di Desa Mengani. Salah satu indikator pada dimensi konteks yang belum dapat mendukung efektifnya program bantuan Simantri di Desa Mengani tahun 2018 yaitu indikator harapan. Program Simantri dirancang dengan harapan dapat menjadikan kelompok tani yang mandiri akam pangan, papan, pupuk, bio dan bio urine serta bio pestisida. Pada kenyataannya kegiatan integrasi tersebut hanya berlangsung pada awal penerimaan bantuan saja, ini disebabkan karena kurangnya partisipasi dari anggota kelompok, maka untuk itu perlu dilakukan pembinaan lebih lanjut terkait dengan program, sehingga apa yang menjadi harapan dirancangnya program tersebut dapat tercapai.

Pada dimensi input, hasil penelitian menunjukkan bahwa secara umum dimensi input tergolong dalam kriteria kurang efektif seperti indikator sumber daya manusia, manajemen, sarana prasarana dan dana operasional belum mendukung efektinya program Simantri di Desa Mengani. Sedangkan pada indikator sosialisasi dan petunjuk pelaksanaan sudah dapat mendukung berlangsungnya program Simantri di Desa Mengani tahun 2018.

Indikator sumber daya manusia, manajemen, sarana prasarana dan dana operasional dikatakan belum efektif karena tidak terdapat struktur yang jelas, sehingga menyebabkan kurangnya partisipasi dari anggota kelompok. Kurang partisipasi anggota kelompok menyebabkan tidak adanya kegiatan pengolahan limbah ternak menjadi pupuk, bio gas, bio urine serta bio pestisida, selain itu alat yang digunakan untuk mengolah limbah ternak dalam keadaan rusak. Dana operasional dikatakan tidak efektif karena dana yang seharusnya digunakan untuk proses pembuatan limbah tidak dipergunakan sebagaimana mestinya, melainkan dana tersebut dipergunakan untuk pembelian bibit sapi sebagai ganti sapi yang telah mati sebelumnya. Untuk itu diperlukan pengawasan secara intensif terhadap program tersebut agar apa yang menjadi tujuan dirancangnya program ini dapat tercapai.

Pada dimensi proses, hasil menunjukkan bahwa secara umum dimensi proses tergolong dalam kriteria efektif seperti indikator perencanaan program, seleksi program dan penyaluran dana sudah dapat mendukung berlangsunya program yang telah diberikan oleh pemerintah di Desa Mengani. Pada indikator pemanfaatan dana dan monitoring belum dapat mendukung efektinya program Simantri di Desa Mengani.

Pada indikator pemanfaatan dana dan monitoring dikatakan belum dapat mendukung efektifnya program Simantri di Desa Mengani karena dana yang seharusnya dipergunakan untuk pembuatan rumah pakan, pengadaan bibit tanaman pangan perkebunan belum terealisasi, dimana dana tersebut dipergunakan untuk pembelian bibit sapi sebagai ganti sapi yeng telah mati, selain itu monitoring juga belum dikatan dapat mendukung keefektifan program ini karena pengawasan yang dilakukan oleh pemerintah melalui Dinas Pertanian Tanaman Pangan, Huktikultura dan Perkebunan Kabupaten Bangli belum sepenuhnya dilaksanakan sepanjang program ini berlangsung dan tidak melakukan evaluasi terhadap program ini. Padahal monitoring mempunyai peran yang sangat penting dalam keberlangsungan sebuah program. untuk itu perlu dilakukan pengawasan yang intensif serta melakukan evaluasi terhadap program Simantri supaya tujuan dan maksud dirancangnya program ini dapat tercapai.

Pada dimensi produk, hasil penelitian menunjukkan hasil bahwa secara umum dimensi produk tergolong dalam kriteria efektif, dimana ketiga indikator (mengakses sumber pendanaan, pengentasan kemiskinan dan mengurangi pengangguran) sudah dapat mendukung berlangsungnya program Simantri yang telah diberikan oleh pemerintah kepada kelompok tani di Desa Mengani.

Hasil penelitian ini sejalan dengan pendapat (Dantes, 2012) bahwa program 
dikatakan cukup efektif apabila salah satu dimensi memiliki nilai negatif.

\section{SIMPULAN DAN SARAN}

\section{Simpulan}

Evaluasi program Simantri ditinjau dari segi context menunjukkan hasil $\sum f(+)>\sum f$ (-). Dengan demikian, dapat dinyatakan bahwa pada dimensi context, evaluasi program Simantri di Desa Mengani, Kecamatan Kintamani, Kabupaten Bangli Tahun 2018 berada di kategori efektif.

Evaluasi program Simantri ditinjau dari segi input menunjukkan hasil $\sum \mathrm{f}(+)<\sum \mathrm{f}(-$ ). Dengan demikian, dapat dinyatakan bahwa pada dimensi input, evaluasi program Simantri di Desa Mengani, Kecamatan Kintamani, Kabupaten Bangli berada pada kategori kurang efektif.

Evaluasi program Simantri ditinjau dari segi process menunjukkan hasil $\sum f(+)>\sum$ $f(-)$. Dengan demikian dapat dinyatakan bahwa pada dimensi process, evaluasi program Simantri di Desa Mengani, Kecamatan Kintamani, Kabupaten Bangli berada pada kategori efektif.

Evaluasi program Simantri ditinjau dari segi product menunjukkan hasil $\sum f(+)>\sum f$ $(-)$. Dengan demikian dapat dinyatakan bahwa pada dimensi product, evaluasi program Simantri di Desa Mengani, Kecamatan Kintamani, Kabupaten Bangli berada pada kategori efektif.

\section{Saran}

Saran pertama bagi Pemerintah Daerah melalui Dinas Pertanian Kabupaten Bangli selaku pihak yang mengawasi berjalannya program Simantri, disarankan untuk memberikan pembinaan lebih lanjut, melakukan pengawasan yang lebih intensif dan melaksanakan monitoring serta melakukan kegiatan evaluasi terhadap program ini supaya tujuan dan maksud dirancangnya program ini dapat tercapai. Kedua bagi Peneliti lain yang berminat melakukan penelitian mengenai evaluasi program, disarankan untuk memperluas penelitian ini dengan metode yang sama terhadap program yang berbeda, agar hasilnya lebih maksimal terhadap proses evaluasi program yang diberikan oleh pemerintah.

\section{DAFTAR PUSTAKA}

Anugrah, I. S., Sarwoprasodjo, S., Suradisastra, K., \& Purnaningsih, N. 2014. Sistem Pertanian TerintegrasiSIMANTRI: Konsep, Pelaksanaan Dan Perannya Dalam Pembangunan Pertanian Di Provinsi Bali. Forum Penelitian Agro Ekonomi, 32(2), 157176. Retrieved from http://pse.litbang.pertanian.go.id/ind/p dffiles/FAE32-2e.pdf.

Arikunto, S., \& Jabar, C. S. A. 2007. Evaluasi Program Pendidikan. Jakarta: PT. Bumi Aksara.

Arikunto, S., \& Jabar, C. S. A. 2014. Evaluasi Program Pendidikan (Edisi ke-2). Jakarta: PT. Bumi Aksara.

Aryana, A. A. N. B., Budhi, M. K. S., \& Yuliarmi, N. N. 2016. Pengaruh Karakteristik Petani dan Peran Pendamping Terhadap Keberhasilan Simantri di Kabupaten Badung. EJurnal Ekonomi Dan Bisnis Universitas Udayana, 5(4), 689-720.

Dananjaya, I., Suparta, N., \& Setiawan AP, I. G. 2014. Pengaruh Jiwa Kewirausahaan dan Manajemen Agribisnis terhadap Keberhasilan Gapoktan Simantri di Kabupaten Tabanan. Jurnal Manajemen Agribisnis, 2(2), 131-142.

Dantes, N. 2012. Metode Penelitian. Yogyakarta: Andi.

Dewi, N. L. P. R., Utama, M. S., \& Yuliarmi, N. N. 2017. Faktor-faktor yang Mempengaruhi Produktivitas Usahatani dan Keberhasilan Program SIMANTRI di Kabupaten Klungkung. E-Jurnal Ekonomi Dan Bisnis Universitas Udayana, 6(2), 701-728.

Nonci, N. 2017. Implementasi Program Gernas Kakao. Makasar: CV Sah Media.

Pantouw, S., Ngangi, C. R., \& Lolowang, T. F. 2017. Evaluasi Pelaksanaan Program Pengembangan Kawasan Minapolitan Dengan Model CIPP (Contex, Input, Process, Product) Di Kota Belitung. Agri-Sosio Ekonomi Unsrat, 13(3A), 95-118.

Parining, N. 2011. Modal Sosial Dalam Pengembangan Simantri Untuk 
Pemberdayaan Petani di Bali. DwijenAGRO, 2(1), 1-8

Pratiwi, K. R. I., Pascarani, N. N. D., \& Winaya, I. K. 2016. Evaluasi Pelaksanaan Program One Village One Product (OVOP) dalam Pemberdayaan Masyarakat di Desa Pelaga, Kecamatan Petang, Kabupaten Badung. Jurnal Akuntansi, 1(1), 1-9. Retrieved from https://ojs.unud.ac.id/index.php/citizen /article/view/23401

Sardjo, S. dan L. D. 2016. Implementasi Model Evaluasi Formatif Program Pembangunan Sosial (UI, ed.). Jakarta.

Sawerah, S. 2012. Evaluasi Pelaksanaan Program Pengembangan Usaha Agribisnis Perdesaan Pada Usahatani Padi di Desa Sungai Duri II Kecamatan Sungai Kunyit Kabupaten Pontianak. Junal Sains Mahasiswa Pertanian, 1(1), 1-9

Tayibnapis, F. Y. 2000. Evaluasi Program. Jakarta: PT Rineka Cipta.

Yuriani. 2012. Evaluasi Program Kewirausahaan Desa dan Kota Dalam Pengentasan Pengangguran. Jurnal Penelitian Humaniora, 17(1), 98-112. 